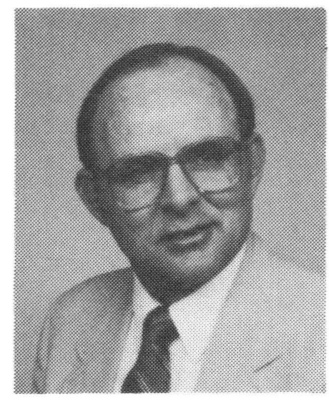

Editorial

Jack D. Gaskill, Editor

\section{Submission of Previously Published Proceedings Papers to Optical Engineering}

For some time now, authors of SPIE Proceedings papers have been receiving, as part of their author's kits, invitations to submit photocopies of their papers to the Editor of Optical Engineering to be considered for publication in that journal. These invitations inform the authors that their papers will be reviewed and, if accepted, that they must be retyped and submitted in the format required for Optical Engineering manuscripts. The invitations have not gone unheeded, and I have been literally deluged with such papers since I became Editor this past July. In fact, I have been receiving far too many submissions of Proceedings papers, and I would like to try to stem the tide.

Let me begin by discussing the differences between the Proceedings and the Journal. These two publications are intended for different purposes and, for the most part, ought to contain different kinds of papers. The Proceedings provide a vehicle for the rapid reporting of ideas, techniques, and results to the engineering community. These reports may be somewhat incomplete, somewhat unpolished, and even somewhat inconclusive; however, it is generally understood that their purpose is to provide snapshots of recent or continuing work and that they are not intended or required to be archival in nature. Optical Engineering, on the other hand, is intended to be archival. Papers submitted to that Journal are expected to be better organized and more polished than Proceedings papers, to contain comparisons of theoretical and experimental results, and to include references to other work, substantiated conclusions, suggestions for future efforts, etc.

Because these two publications are so different, it is my opinion that papers previously published in the Proceedings should not, as a rule, be reprinted in Optical Engineering - at least not without undergoing major revision. However, there will be exceptions to this rule. For example, it may be appropriate to have previously published review papers, which are related to particular areas of optics, published as part of a special issue of the Journal addressing that particular area. Similarly, a previously published Proceedings paper might be appropriate for publication in the Journal with little or no revision as long as it satisfies the purposes and requirements of each publication. Still, there should not be widespread dual publication of the same papers without substantive revision.

I wish to address one last item: by being invited to send photocopies of Proceedings papers, authors have been encouraged to submit manuscripts they might otherwise not have submitted. In other words, they have been encouraged to take a chance, and many have done so. That is where the problem is created. There are only a finite number of referees, and I simply can't afford to exhaust my supply by asking them to decide whether or not a paper might be acceptable if it were to be revised, expanded, updated, etc. If an author feels that his or her paper is of an archival nature, is of sufficiently high quality, and wants to have it published in Optical Engineering, then that author should be willing to submit it according to the required format, outlined in the "Information for Contributors to Optical Engineering" page published in each issue of the Journal. If authors do not comply with these instructions, the review process may be slowed considerably.

It is with this philosophy in mind that the Proceedings author kit invitations are being replaced with a new statement about submitting Proceedings manuscripts to the Journal, and with guidelines for doing so. It is my hope that this approach will expedite the review process for all Journal submissions as well as encourage authors to update, revise, expand, or polish, as appropriate, the papers they submit to the archival literature.

\section{OPTICAL ENGINEERING EDITORIAL SCHEDULE}

\section{February 1986}

$\begin{aligned} & \text { Materials and Devices for } \\ & \text { Optical Information Processing }\end{aligned}$
$\begin{array}{ll}\text { Cardinal Warde } & \text { Uzi Efron } \\ \text { M.I.T. } & \text { Hughes Research Labs. } \\ \text { Room 13-3134 } & \text { M.S. RL69 } \\ \text { Cambridge, MA 02139 } & \text { 3011 Malibu Canyon Rd. } \\ \text { 617/253-6858 } & \text { Malibu, CA 90265 } \\ & \text { 213/317-5214 }\end{array}$

\section{March 1986}

\begin{tabular}{|c|c|}
\hline \multicolumn{2}{|c|}{ Applications of Artificial Intelligence } \\
\hline $\begin{array}{l}\text { Mohan M. Trivedi } \\
\text { Louisiana State Univ. } \\
\text { Dept. of Electrical and } \\
\text { Computer Engineering } \\
\text { Baton Rouge, } \\
\text { LA 70803-5901 } \\
\text { 504/388-5241 }\end{array}$ & $\begin{array}{l}\text { John F. Gilmore } \\
\text { Georgia Tech Research } \\
\text { Institute } \\
\text { Artificial Intelligence Branch } \\
\text { Atlanta, GA } 30332 \\
\text { 404/894-3471 }\end{array}$ \\
\hline
\end{tabular}

May 1986

Optics for the Space Station

Henry Lum

Information Sciences, Code SI

Mail Stop 244-7

NASA Ames Research Center

Moffett Field, CA 94035 415/694-6544

June and July 1986

\section{Speckle I and II}

Henri H. Arsenault Université Laval

Lab. de recherches en optique et laser

Département de physique

Ste-Foy, Quebec

G1K 7P4 Canada

418/656-2650

\author{
Joseph W. Goodman \\ Stanford University \\ Dept. of Electrical \\ Engineering \\ Durand Bldg. 127 \\ Stanford, CA 94305 \\ 415/497-3304
}

\section{August 1986}

\section{X-Ray Optics}

Gerald F. Marshall

Ovonic Synthetic Materials Co.

Division of Energy Conversion Devices, Inc. 1788 Northwood Dr.

Troy, MI $48084 \quad 313 / 362-1290$

\section{September 1986}

\author{
Large Optics Technology \\ Gregory M. Sanger \\ United Technologies Research Center \\ Optics and Applied Technologies Laboratories \\ P.O. Drawer 4181 \\ West Palm Beach, FL 33402 305/863-4155
}

\section{October 1986}

\section{Optical Interconnections}

Lynn D. Hutcheson

Honeywell Inc.

10701 Lyndale Ave. South

Bloomington, MN 55420 612/887-4052 